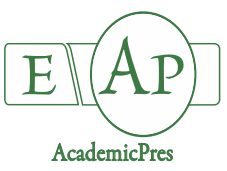

Lyu C et al. (2020)

Notulae Botanicae Horti Agrobotanici Cluj-Napoca 48(2):849-861

DOI: $10.15835 /$ nbha48211837

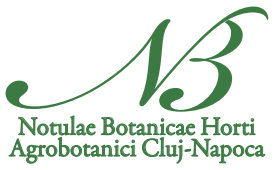

\title{
Influence of ridges for planting sweet potato on symbiotic ecological factors, photosynthetic abilities and population yield in relay intercropping system
}

\author{
Changwen $\mathrm{LYU}^{1,2 *}$, Daobin TANG ${ }^{1,2}$, Kai ZHANG ${ }^{1,2}$, Jichun WANG ${ }^{1,2 *}$ \\ ${ }^{1}$ Southwest University, College of Agronomy and Biotechnology, Beibei, Chongqing 400715, \\ China;lvcgwn@163.com; tdbin741023@163.com; zhangkai2010s@163.com; wjchun@swu.edu.cn('correspondingauthor) \\ ${ }^{2}$ Key Laboratory of Biology and Genetic Improvement for Tuber and Root Crops in Chongqing, Beibei, Chongqing 400715, China
}

\begin{abstract}
Sweet potato (Ipomoea batatas L.) relay intercropping with maize exposes sweet potato to weak levels of sunlight due to the shadow maize creates during the symbiotic period. The insufficient light accordingly causes slow growth and development of vines and leaves of sweet potato in its early stage. The planting density and row direction of maize, the width of the intercropping strip, and the lodging type of sweet potato may form various photo conditions that influence sweet potato. The objective of this experiment was to research the effects of different ridging types on sweet potato and to elucidate the mechanisms of ecological conditions, photosynthetic physiology and intercropping benefits. The results indicated that, contrast to the one wideridge with planting two rows of sweet potato and two narrow ridges with planting two rows, mound planting was more superior in many aspects. Through mound planting sweet potato showed a larger range of temperature in air and soil, higher net photosynthetic rate, more active enzymes related with photosynthesis, and more benefits of relay intercropping.
\end{abstract}

Keywords: environmental factors; land equivalent ratio; relay intercropping; ridging type; sweet potato; symbiotic period

\section{Introduction}

Sweet potato (Ipomoea batatas L.) is widely used for food, feedstock and industrial materials and is mainly cultivated in tropical and subtropical areas. Sweet potato is cultivated in more than 100 countries all over the world. It ranks as the seventh largest crop after corn, wheat, rice, soybean, cotton, potato (Ma, 2013; Zhang, 2015). About 96\% of sweet potato comes from Asia and Africa. Chongqing is a province-level municipality that is located in southwestern China and is one of the main and traditional sweet potato zones. Relay intercropping with maize has been found to be the most common mode for sweet potato cultivation in this area.

The intercropping is feature, as it gives a relatively stable yield (Wells et al., 2000; Skelton et al., 2005) and it has more merits than single cropping, such as improving the fertilizer utilization efficiency, conservation of the soil fertility, it cuts down the soil erosion (Willey, 1979; Mead et al., 1980; Beets, 1982; Clawson, 1985; 
Wolfe, 1985). The benefits of intercropping had been identified by many planting examples in the past. For example, soybean intercropping with maize makes good use of water, heat and nutrients and allows more product in same planting area as a result (Liu et al.,2004). Further, studies have indicated that the intercropping system benefits from its larger leaf area, various roots distribution of this community, and forms one small ecosystem to lessen water evaporation and strengthen the absorption and transportation of soil water (Coll $e t$ al., 2012; Liu et al., 2013). However, maize is one of the popular crops used for intercropping, it always influences other short crops such as sweet potato, soybean and potato. Creating one appropriate environment for these crops is essential to increase intercropping population yields (Rezaei-Chianeh et al., 2011). For two or three crops grown by intercropping, photo utilization determines their growth development and the final economic products (Prithiviraj et al., 2000).

There is some competition among different crops in intercropping systems. Contrast to the planting mode of wheat/maize/soybean, relay intercropping of wheat/maize/sweet potato is advantageous in that it allows maize to absorb and accumulate phosphorus fertilizer. While it is unfavourable for maize to utilize the nitrogen fertilizer in this planting system and the fertilizer would move from maize to sweet potato in soil (Yong et al., 2009; Yong et al., 2012).

Experiencing a lower level of light caused by preceding crops, leads to those crops ripening later in the relay intercropping system. However, they will have exposure to normal sunlight conditions after harvesting the preceding crops. Sometimes, delayed ripening can cause the crops to suffer from photo inhibition; while some crops will recover within an hour, others may have more effects. Sudden bright light will trigger the light protection mechanism of crops (Xu, 1977; Liu et al., 2001). Escaping from weak light stress, different cultivars of soybean would have various levels of recovery (Liu et al., 2015). After ten continuous days of illumination at $60 \%$ the normal light intensity, the photo inhibition was found to occur in several wheat varieties (Zhou et al., 2015).

In relay cropping systems of maize and sweet potato, except for planting density and row direction of maize, sweet potato is affected by cultivars and ridging modes and even the ridging mode would bring about more significant effects (Zhu et al., 1993). In southwestern China there are three types of ridging modes, the yield of sweet potato plant on wide-ridge is the highest in relay intercropping. $\mathrm{Li}$ (1995) testified that Mound planting for sweet potato was superior to the traditional ridging in the compound system.

In this study, we tested three common relay intercropping modes in maize and sweet potato, with diverse ridging types (wide-ridge, narrow-ridge and soil-mound) for sweet potato, and discovered novel and systematic rules. This mechanism of population yield formation for maize/sweet potato will play an important role in how we reconsider and improve the management strategies of relay intercropping in production.

\section{Materials and Methods}

The cultivars 'Xida-985' (semi compact corn) and 'Yushu-33' (high-starched sweet potato with short vines) were used as the materials for this experiment. They were planted with the relay intercropping system and welcomed by local farmers in southwestern China.

\section{The experimental site}

The experiment was implemented at the base of the Institute of Southwest University Tuberous Crops in Xiema, Beibei of Chongqing, China in 2015 and 2016. The soil fertility and meteorological conditions were shown in following Table 1 and Table 2. 
Lyu C et al. (2020). Not Bot Horti Agrobo 48(2):849-861

Table 1. Basic soil fertility

\begin{tabular}{|c|c|c|c|c|c|c|c|c|}
\hline \multirow{2}{*}{ Year } & \multirow{2}{*}{$\mathrm{pH}$} & $\begin{array}{c}\text { Available } \\
\text { potassium }\end{array}$ & $\begin{array}{c}\text { Effective } \\
\text { phosphorus }\end{array}$ & $\begin{array}{c}\text { Alkaline } \\
\text { nitrogen }\end{array}$ & $\begin{array}{c}\text { Organic } \\
\text { matter }\end{array}$ & $\begin{array}{c}\text { Total } \\
\text { nitrogen }\end{array}$ & $\begin{array}{c}\text { Total } \\
\text { phosphorus }\end{array}$ & $\begin{array}{c}\text { Total } \\
\text { potassium }\end{array}$ \\
\cline { 3 - 9 } & & $(\mathrm{mg} \cdot \mathrm{kg}-1)$ & & $(\%)$ & \multicolumn{4}{|c|}{$\left(\mathrm{g}^{-1} \mathrm{~kg}^{-1}\right)$} \\
\hline 2015 & 5.23 & 206.853 & 57.825 & 53.470 & 11.430 & 0.419 & 1.039 & 44.948 \\
\hline 2016 & 6.64 & 172.610 & 19.159 & 81.995 & 10.401 & 0.550 & 1.141 & 43.866 \\
\hline
\end{tabular}

Table 2. Basic meteorology information during the experimenting (From March to October)

\begin{tabular}{|c|c|c|c|c|c|c|c|c|c|}
\hline & Index & 3 & 4 & 5 & 6 & 7 & 8 & 9 & 10 \\
\hline \multirow{3}{*}{2015} & Mean temperature $\left({ }^{\circ} \mathrm{C}\right)$ & 14.8 & 20 & 23.6 & 25.8 & 27.6 & 26.9 & 23.3 & 20.1 \\
\cline { 2 - 10 } & Mean rainfall $(\mathrm{mm})$ & 25 & 100 & 110 & 250 & 180 & 225 & 210 & 70 \\
\cline { 2 - 10 } & Mean duration of sunshine $(\mathrm{hr})$ & 118 & 115 & 95 & 85 & 205 & 203 & 55 & 95 \\
\hline \multirow{3}{*}{2016} & Mean temperature $\left({ }^{\circ} \mathrm{C}\right)$ & 13.5 & 17.8 & 22.5 & 26.1 & 30.8 & 32.3 & 23.6 & 19.5 \\
\cline { 2 - 10 } & Mean rainfall $(\mathrm{mm})$ & 55 & 75 & 125 & 313 & 178 & 100 & 150 & 98 \\
\cline { 2 - 10 } & Mean duration of sunshine $(\mathrm{hr})$ & 85 & 80 & 120 & 141 & 226 & 198 & 65 & 92 \\
\hline
\end{tabular}

\section{Experimental design}

Single factor randomized block design was applied in this experiment. The experimental factor is the ridging mode, which included three levels (Figure 1). One that was wide-ridge planted with two small columns of sweet potato between wide rows of maize (A), two narrow ridges planted in two columns of sweet potato close to the maize rows (B), and nine mounds of sweet potato planted between wide rows of maize (C). The height of the wide-ridge, the narrow-ridge and mound were all 30-centimeter. Every treatment had three duplicates and every duplicate included four one-meter stripes. In addition, the same ridging modes were applied to planting sweet potato and maize in single cropping to measure the land equivalent ratio (LER). The planting densities for maize and sweet potato were 4000 plants and 3300 plants every $667 \mathrm{~m}^{2}$ respectively.

\section{Field management}

The maize seeds sowed in seedling plates on March 15 and were transplanted on April 11, 2015. And another group sowed on March 18 and transplanted on April 19, 2016. Sweet potato tuberous roots sowed in the soil to culture seedlings on March 15, 2015 and 2016. Sweet potato seedlings with five top nodes were transplanted on May 14, 2015 and on May 15, 2016. Maize and sweet potato fertilized with the same method. $16.7 \mathrm{~kg}$ compound fertilizer (14-15-16) and $4.7 \mathrm{~kg}$ phosphate fertilizer were applied per $667 \mathrm{~m}^{2}$. Other management measures were the same as the local planting sweet potato do.

\section{Sampling and testing}

We sampled sweet potatoes at the $35,50,65$ and 80 days after transplanting (DAP) period. During the symbiotic stage, sweet potato was tested three times $(35,50$ and $65 \mathrm{DAP})$, and the last time was at $80 \mathrm{DAP}$ (15 days after harvesting maize). We detected five sweet potato samples/plants for every duplicate. The leaves of sweet potato were collected in field and stored in $-40^{\circ} \mathrm{C}$ fridge for detecting the activity of enzymes. Total plants used to assay the nutrition content. All soil samples close to sweet potato roots used to detect the microbial biomass.

\section{Aerial and soil temperature}

The aerial temperature would be record automatically with the TPJ20 Temperature and Moisture Apparatus (Zhejiang Tuopu Apparatus Limited Corp.) at the position of $5 \mathrm{~cm}$ higher than the canopy of sweet potato in continuous three days. The soil temperature was measured through that machine' probes inserting 
the centre position between two sweet potato plants for $\mathrm{A}$ and $\mathrm{B}$, and inserting 5 positions including the centre and 4 surrounding sites planted sweet potato of the $\mathrm{C}$.

\section{Soil moisture}

After bringing away the sweet potato as the samples, mixing the left soil thoroughly from $0-15 \mathrm{~cm}$ soil and $15-30 \mathrm{~cm}$ soil respectively, and loading the soil into the aluminium box (M1), weighing the total weight (M2), and then drying them completely and weigh the total weight again (M3). The soil moisture content (SMC) would be calculated according to the following formula:

$$
\mathrm{SMC}=\frac{\mathrm{M} 2-\mathrm{M} 3}{\mathrm{M} 2-\mathrm{M} 1} \times 100 \%
$$

\section{$\mathrm{CO}_{2}$ concentration}

Testing dates were the same as the days of testing soil temperature above. And the concentration was detected by Telaire 7001(GE, USA) from 9 to 11 in the morning. The testing sites included the top, middle and bottom of sweet potato canopy and the average of the three sites represented the $\mathrm{CO}_{2}$ concentration of the canopy.

\section{Photosynthetically available radiation}

(PAR): PAR was record by the LI-191SA (Li-Cor Inc., Nebraska, USA) at every two hours from 8 a.m. to 18 p.m. in continuous three days. The testing site was located at the top of sweet potato canopy of every duplicate.

\section{Photosynthetic parameters}

Net photosynthetic rate $(\mathrm{Pn})$, transpiration rate $(\mathrm{Tr})$, stomatal conductance (Cond) and intercellular $\mathrm{CO}_{2}$ concentration $(\mathrm{Ci})$ were record through Li-6400 (Li-Cor Inc., Nebraska, USA) every two hours from a.m. 8 to 18 p.m. in 7 sunny days continuously.

\section{Key enzymes about photosynthesis}

Grind $0.5 \mathrm{~g}$ sweet potato leaves stored at $-40^{\circ} \mathrm{C}$ to a fine powder using liquid nitrogen. Then add $4.5 \mathrm{ml}$ $1 / 15$ M PBS ( $\mathrm{pH} 7.3$ ) into the mortar and mix them thoroughly. Transfer the extract mixture to the $5 \mathrm{ml}$ centrifuge tube and spin the tube at $4000 \mathrm{rpm}$ for $15-20 \mathrm{~min}$ at $4^{\circ} \mathrm{C}$. And transfer $1 \mathrm{ml}$ the supernatant to test Ribulose-1,5-bisphosphate carboxylase/oxygenase (RuBisco, E.C4.1.1.39) and Sucrose-phosphate synthase (SPS, E.C2.4.1.14). According to the protocol, test the OD of the two enzymes at $495 \mathrm{~nm}$ and $290 \mathrm{~nm}$ respectively by the ways of Enzyme-Linked Immuno Sorbent Assay, ELISA), and calculate the concentration of enzymes (U/L) through the standard curve.

\section{$\underline{\text { Soil microbial biomass }}$}

Detect the microbial biomass carbon (MB-C) and microbial biomass nitrogen (MB-N) of the soil samples through the fumigation-extraction with chloroform and $\mathrm{K}_{2} \mathrm{SO}_{4}$; Test the microbial biomass phosphorus (MB-P) through the fumigation-extraction with chloroform and $\mathrm{NaHCO}_{3}$ (Wu et al., 2006).

For the dry plant samples of sweet potato, the total nitrogen was measured by the Kelvin distillation, the determination of total phosphorus was set by $\mathrm{NaOH}$ melting a molybdenum antimony resistance to colorimetric method, and the total potassium was determined by the method of $\mathrm{NaOH}$ melting flame photometry (Bao, 2000). 


\section{Yield and land equivalent ratio (LER)}

\section{Maize yield}

Harvest maize in relay intercropping and single cropping systems, dried the grains, weighed and labelled them with Yrm and Ysm respectively.

\section{Sweet potato yield}

Harvest the tuberous roots and weigh them from in relay intercropping and single cropping systems, weighed and labelled them with Yrsp and Yssp respectively.

LER $=\frac{\text { Yrm }}{\text { Ysm }}+\frac{\text { Yrsp }}{\text { Yssp }}$

Notes: In the equation, Yrm and Yrsp represent the yields of maize and sweet potato in relay intercropping system, while Ysm and Yssp represent the yields of maize and sweet potato in single cropping respectively. That LER is more than 1 suggests the relay intercropping system be of intercropping superiority in production (Liu and Zhang, 1994).

In the paper, two-year experimental data did not list in most figures and tables respectively, while the average of the data was applied in figures and tables. The experimental data was arranged, analysed and drawn with the software Excel 2010. The analysis of variance (Duncan, $a=0.05$ ) and correlation analysis were carried out by SPSS 21.

\section{Results}

\section{Diurnal changes of photosynthetically available radiation (PAR)}

Maize is the crop with tall erect stem, which is superior to sweet potato during symbiotic time at the aspect of receiving sunshine. In this experiment, the upper PAR of maize plants was not obviously different between 2015 and 2016. The mean values of PAR from three treatments were $C>A>B$, among which $C$ and A had no significant difference. However, both of them were notable higher than B. From Figure 1 the diurnal PAR tendency of three treatments was almost identical and similar. The emergence of the highest PAR from $B$ was earlier than $A$ and $C$. It may attribute to that $B$ was nearer to corn plants and the two others were the middle intercropping belt. In addition, the significant differences were found between three treatments at early morning (8:00) and late afternoon (18:00). When light intensity was strong or air temperature was high, the similar PAR of A and C were higher than B significantly.

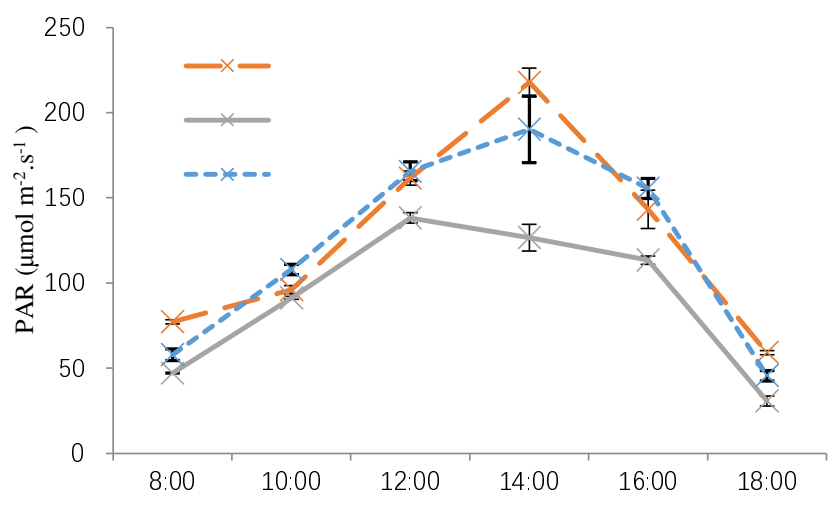

Figuri 1. Diurnal PAR changes of sweet potato canopy in different ridging modes Note: The error bar represents the standard error (the same as below) 


\section{Comparison of carbon dioxide $\left(\mathrm{CO}_{2}\right)$ concentration in different treatments}

We found from Figure 2 that $\mathrm{CO}_{2}$ concentration from sweet potato canopy of $\mathrm{A}$ and $\mathrm{C}$ was stable before 50 days after planting. With the leaves of maize aging until harvesting it, that of three treatments decreased more or less. In totally, the concentration of B was the highest during symbiotic period, while 15 days after harvesting maize, the concentration of A was higher than other two treatments greatly, which may have something to do with wide-ridge planting with narrow row spacing of sweet potato and poor ventilation.

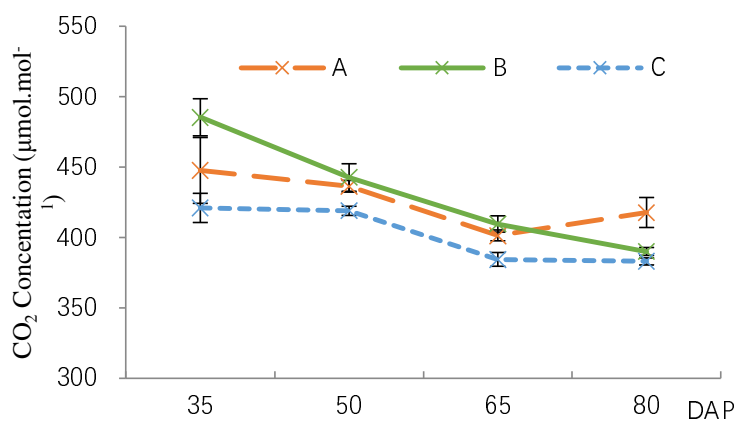

Figuri 2. Dynamic changes of $\mathrm{CO}_{2}$ concentration in different ridging modes Note: 35DAP, 50DAP, 65DAP and 80DAP mean the $35^{\text {th }}, 50^{\text {th }}, 65^{\text {th }}$ and $80^{\text {th }}$ days after transplanting sweet potato respectively, $80 \mathrm{DAP}$ represents 15 days after maize harvesting (the same as below).

\section{Soil quality water content of sweet potato in different ridge planting modes}

The ridging mode had little effect on soil quality water content (SQWC) in early symbiotic period (35DAP), and from 35 DAP to 65 DAP SQWC of A and B kept higher than C. After that time, the SQWC of all treatments decreased dramatically (Figure 3). During symbiotic period the soil kept higher moist. While after harvesting maize, the soil became more arid. Consequently, it is obvious that the maize played a great role in shading and keeping high soil water. Meanwhile the narrow-ridge treatment became less moist than the other two without the corn shading since 65 DAP.

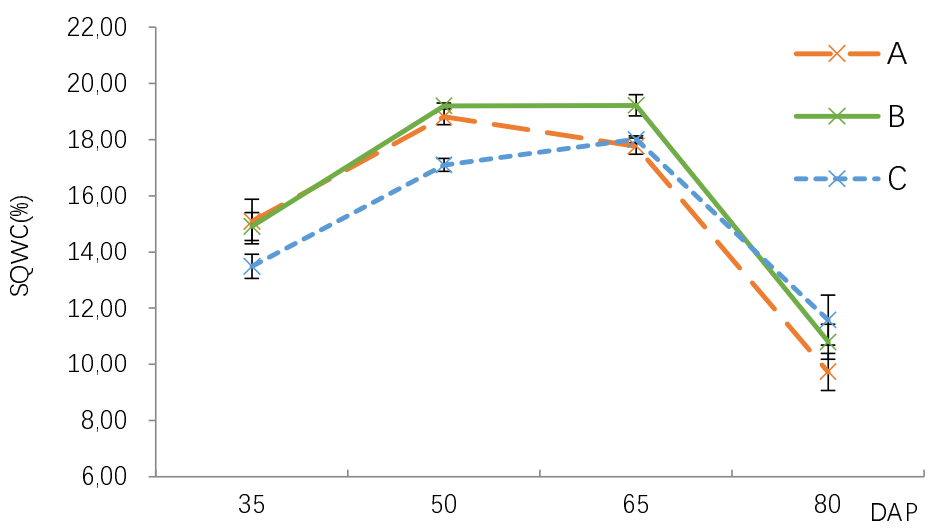

Figure 3. Effect of different ridging modes on soil moisture content

\section{Temperature changes of sweet potato canopy and rhizosphere soil}

Temperature is one of the important environmental factors influencing on sweet potato growing. At 65 DAP, The air temperature reached the summit at 14:00 and soil at 16:00 respectively. The air temperature difference is more than soil temperature greatly (Figure 4). Especially for both air and soil temperature of mound planting, the range was the most among three treatments. This also indicated that the pile-ridge was beneficial to absorb and scatter heat. 
Lyu C et al. (2020). Not Bot Horti Agrobo 48(2):849-861
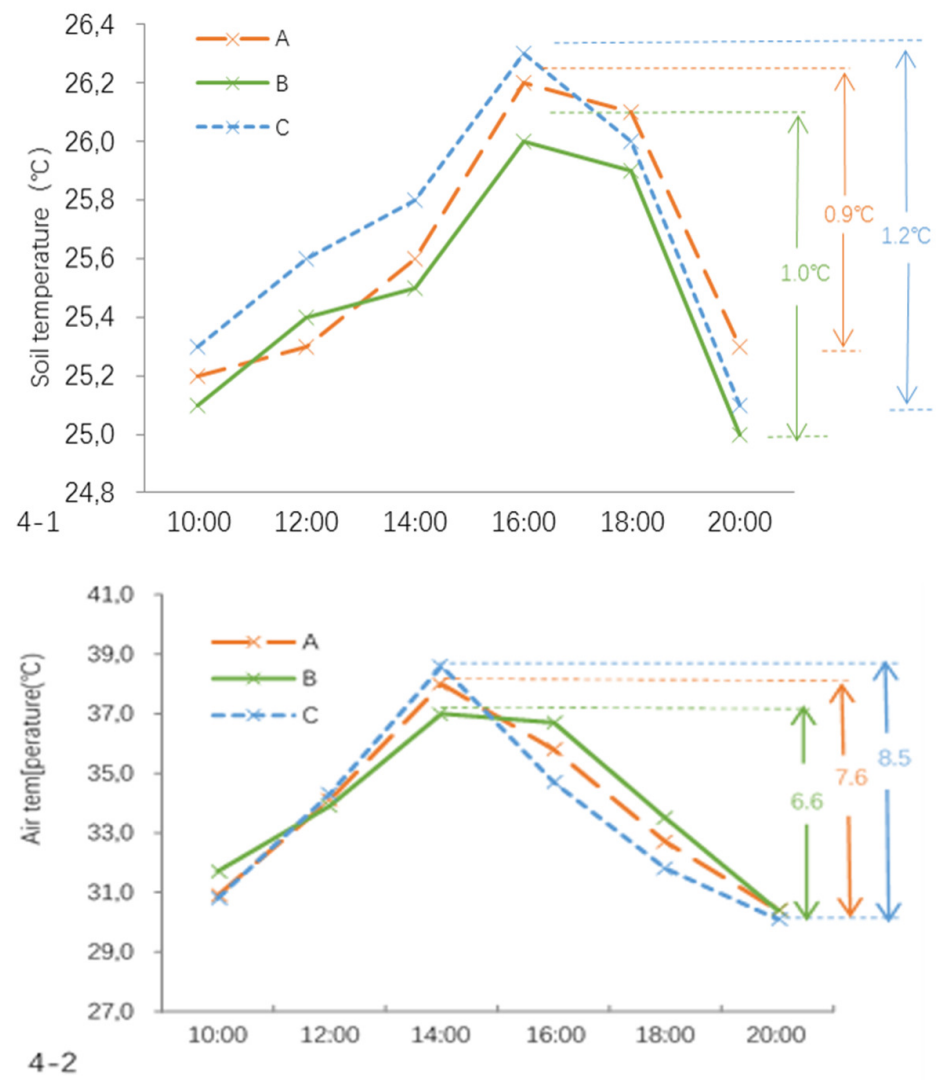

Figure 4. Diurnal variation of soil (4-1) and air (4-2) temperature in different ridging modes

The net photosynthetic rate $(\mathrm{Pn})$ always took on one best performance for mound plating $(\mathrm{C})$ while $\mathrm{Pn}$ of narrow-ridge was lower relatively in most time. For three treatments, the time of their reaching the summit was not unanimous. The treatment $\mathrm{C}$ was the first one realizing the optimal $\mathrm{Pn}$ while $\mathrm{B}$ was the last one from the Figure 5. However, for Transpiration rate $(\operatorname{Tr})$, its diurnal changing tendency looked similar to the changes of air temperature (Figures 4-2), and all treatments reached the peak of $\operatorname{Tr}$ at 14:00. From 10:00 to 20:00, the $\operatorname{Tr}$ of $\mathrm{C}$ was higher than other two treatments. In general, whether $\operatorname{Pn}$ or $\operatorname{Tr}$ of $\mathrm{C}$ was higher than other ridging modes significantly. On the contrary, narrow-ridge is disadvantageous for improving $\mathrm{Pn}$ and $\mathrm{Tr}$ of sweet potato during symbiotic period, and also it is averse to accumulating photosynthates.
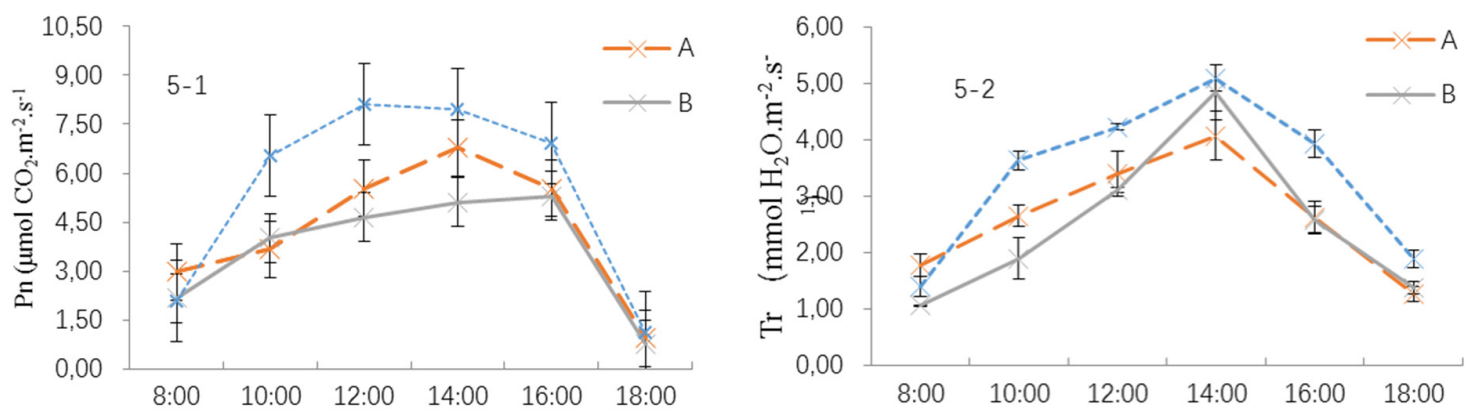

Figure 5. Effect of ridging modes on $\operatorname{Pn}(5-1)$ and $\operatorname{Tr}(5-2)$ of sweet potato 


\section{Ribulose-1,5-bisphosphate carboxylase/oxygenase for fixing dioxide}

Sweet potato is one of the $\mathrm{C} 3$ crops and RuBisco plays a decisive role in assimilating $\mathrm{CO}_{2}$ in $\mathrm{Calvin}$ Cycle. It was obvious that the activity of RuBisco was weaker during symbiotic time than after harvesting maize in this experiment. It also varied with different treatments according to the Figure 6 . The enzyme of $C$ was the most active while $\mathrm{B}$ was the weakest one. Compared with the RuBisco activity, when sweet potato intercropping with maize in early stage, it was promoted by $38.04 \%, 25.65 \%$ and $30.31 \%$ for A, B and C after harvesting maize respectively. Those indicated that the ability of assimilating $\mathrm{CO}_{2}$ would decrease because of maize shadow. As a result, mound planting was superior to other ridging modes about RuBisco activity.

Sucrose phosphate synthase (SPS) then is the essential enzyme for synthesizing sucrose in tuberous root formation of sweet potato. Apparently SPS also affected by various ridging modes greatly. At symbiotic stage, the activity of SPS decreased gradually more or less for all treatments. 15 days after harvesting corn, the activity recovered higher than before immediately. In addition, according to Figure 7 mound planting was the optimal mode of high SPS activity and the narrow-ridge was the worst in relay intercropping system.

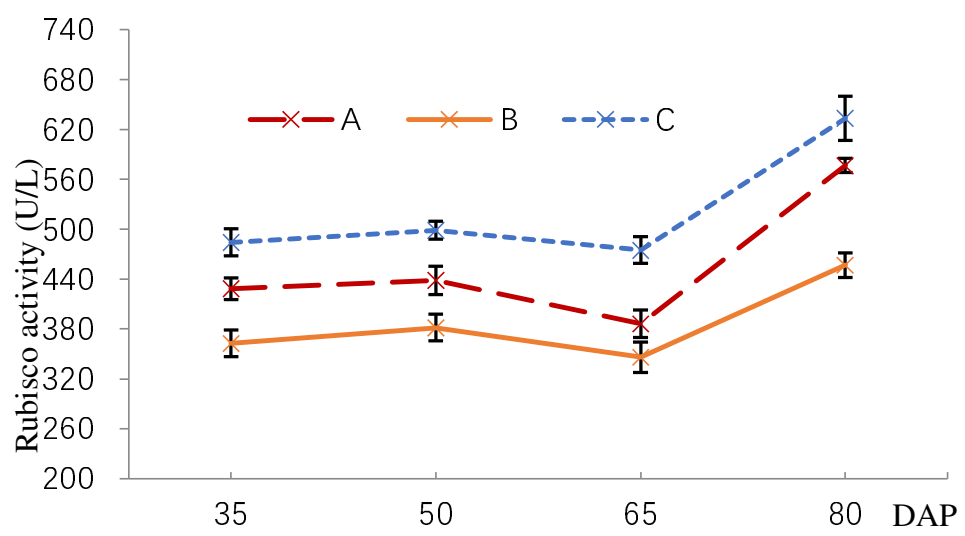

Figure 6. Effect of ridging modes on the activity of RuBisco in sweet potato leaves

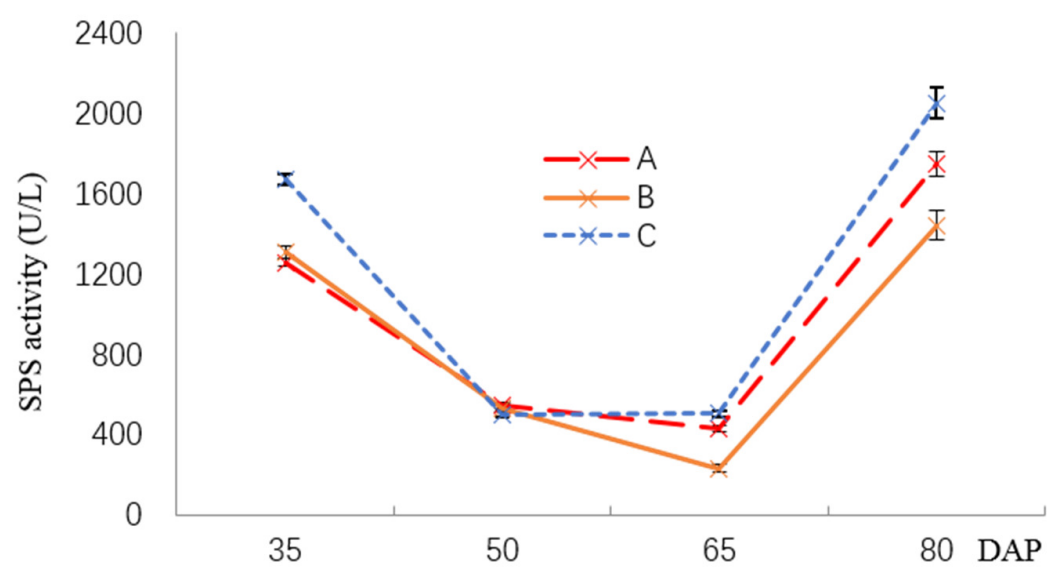

Figure 7. Effect of ridging modes on the activity of SPS in sweet potato leaves

\section{Content of soil microbial biomass in three treatments}

Soil microbial biomass from different treatment was measured in 0-30 $\mathrm{cm}$ depth soil. Microbial biomass carbon $(\mathrm{MBC})$ and microbial biomass nitrogen $(\mathrm{MBN})$ from $0-15 \mathrm{~cm}$ soil layer were more than that from $15-$ $30 \mathrm{~cm}$ soil layer of every treatment respectively in Table 3 . The content of them was also various with different ridging modes. For the content of both $\mathrm{MBC}$ and $\mathrm{MBN}$, A was the lowest while $\mathrm{C}$ was the highest from 0-15 
$\mathrm{cm}$ or 15-30 $\mathrm{cm}$ depth soil. But for microbial biomass phosphorus $C$ was the lowest in both $0-15 \mathrm{~cm}$ and 15-30 $\mathrm{cm}$ depth soil. There were significant differences among various treatments about $\mathrm{MBC}, \mathrm{MBN}$ and $\mathrm{MBP}$, all of which further affects abstracting efficiency about fertilizers, such as nitrogen, phosphorus, potassium and so on.

Table 3. The comparison of soil microbial biomass in $30 \mathrm{~cm}$-depth soil

\begin{tabular}{|c|c|c|c|c|}
\hline \multirow{3}{*}{ Soil layer } & \multirow{2}{*}{ Treatment } & $\begin{array}{c}\text { Microbial biomass } \\
\text { carbon }\end{array}$ & $\begin{array}{c}\text { Microbial biomass } \\
\text { nitrogen }\end{array}$ & $\begin{array}{c}\text { Microbial biomass } \\
\text { phosphorus }\end{array}$ \\
\cline { 2 - 5 } & & \multicolumn{2}{|c|}{$\mathrm{mg} \cdot \mathrm{kg}^{-1}$} & $17.35 \mathrm{~d}$ \\
\hline \multirow{3}{*}{$0-15$} & A & $277.50 \mathrm{c}$ & $11.40 \mathrm{c}$ & $18.97 \mathrm{~b}$ \\
\cline { 2 - 5 } & B & $305.31 \mathrm{a}$ & $12.79 \mathrm{ab}$ & $17.15 \mathrm{~d}$ \\
\cline { 2 - 5 } & C & $310.08 \mathrm{a}$ & $13.05 \mathrm{a}$ & $20.06 \mathrm{a}$ \\
\hline \multirow{3}{*}{$15-30$} & & & & $18.72 \mathrm{~b}$ \\
\cline { 2 - 5 } & A & $264.27 \mathrm{~d}$ & $10.77 \mathrm{~d}$ & $18.05 \mathrm{c}$ \\
\cline { 2 - 5 } & B & $289.23 \mathrm{~b}$ & $11.66 \mathrm{c}$ & $12.42 \mathrm{~b}$ \\
\hline
\end{tabular}

\section{Absorption of macro-elements of sweet potato in different ridging modes}

The content of those macro-elements was different correspondingly showed as Table 4. Among three treatments, B absorbed most nutrition of nitrogen, which resulted from narrow space between sweet potato and maize. However, the total phosphorus of $\mathrm{A}$ and potassium of $\mathrm{C}$ were the lowest compared with other ridging modes respectively. These also indicated that various ridging modes would lead different absorbing nutrient of sweet potato in relay intercropping system.

Table 4. The plant nutrient content of sweet potato in different ridging modes

\begin{tabular}{|c|c|c|c|}
\hline Treatments & $\begin{array}{c}\text { Total nitrogen } \\
(\mathrm{N})\end{array}$ & $\begin{array}{c}\text { Total phosphorus } \\
\left(\mathrm{P}_{2} \mathrm{O}_{5}\right)\end{array}$ & $\begin{array}{c}\text { Total potassium } \\
\left(\mathrm{K}_{2} \mathrm{O}\right)\end{array}$ \\
\hline \hline $\mathrm{A}$ & $184.91 \mathrm{c}$ & $51.47 \mathrm{~b}$ & $220.07 \mathrm{a}$ \\
\hline $\mathrm{B}$ & $210.14 \mathrm{a}$ & $57.98 \mathrm{ab}$ & $190.12 \mathrm{~b}$ \\
\hline $\mathrm{C}$ & $196.72 \mathrm{~b}$ & $64.23 \mathrm{a}$ & $181.96 \mathrm{~b}$ \\
\hline
\end{tabular}

\section{Comparison of community yielding and relay intercropping benefit}

From the Table 5, the sweet potato yield of different treatment performed in relay intercropping system, and it always took on the tendency of $\mathrm{C}>\mathrm{A}>\mathrm{B}$ in both 2015 and 2016. In fact, the production of sweet potato was higher in 2015 because maize lodging decreased shadow in advance. As the higher crop planted firstly in the relay intercropping mode, maize yield was affected little by sweet potato and no significant difference was found among treatments.

Furthermore, land equivalent ratio (LER) is the measurement standard for intercropping farming system. In the experiment, The LER of treatment $B$ was only just about 1.00 , which meant no intercropping advantages, but treatment $C$ had obvious more advantages than $B$ and $A$ in 2015-2016. All these indicated that it was more effective that mound planting was applied and farmers could be acquiring more benefits in relay intercropping system. 
Lyu C et al. (2020). Not Bot Horti Agrobo 48(2):849-861

Table 5. The analysis of the yield under different ridging modes in two years

\begin{tabular}{|c|c|c|c|c|}
\hline & \multirow{2}{*}{ Treatments } & \multicolumn{2}{|c|}{ Yield $\left(\mathrm{kg} \cdot \mathrm{hm}^{-2}\right)$} & \multirow{2}{*}{ LER } \\
\hline & & Fresh tuberous root & Maize grain & \\
\hline \multirow{3}{*}{2016} & $\mathrm{~A}$ & $13485.52 \mathrm{~b}$ & $6844.27 a$ & $1.15 \mathrm{~b}$ \\
\hline & $\mathrm{B}$ & $10417.33 c$ & $6524.84 a$ & $1.00 \mathrm{c}$ \\
\hline & $\mathrm{C}$ & $15328.87 \mathrm{a}$ & $6766.57 \mathrm{a}$ & $1.34 \mathrm{a}$ \\
\hline \multirow{3}{*}{2015} & $\mathrm{~A}$ & $18027.19 a$ & 6452.49ab & $1.08 \mathrm{~b}$ \\
\hline & $\mathrm{B}$ & $13976.68 b$ & $6230.06 \mathrm{~b}$ & $1.03 \mathrm{~b}$ \\
\hline & $\mathrm{C}$ & $18275.80 \mathrm{a}$ & $6651.25 \mathrm{a}$ & $1.23 \mathrm{a}$ \\
\hline
\end{tabular}

\section{Discussion}

In this experiment, sunlight, temperature (air and soil) and water (soil humidity) influenced sweet potato growth and development more or less. And different ridging types result in various ecological environment for sweet potato. Under these circumstances sweet potato gradually forms different adaptabilities correspondingly and the output of tuberous roots was affected eventually. Although the maize shadow was treated as a disadvantageous factor leading less production of sweet potato in the relay intercropping (Gliessman, 1985; Oswald et al., 1995; Nedunchezhiyan et al., 2012), it was not the direct reason for yield loss. In fact, through the correlation analysis we found that, as the environmental factor, PAR was not the direct reason for yield loss of sweet potato, but $\mathrm{CO}_{2}$ concentration and soil humidity had negatively significant effects on tuberous root formation and tuberization.

Just as Wanget al. (2004) reported, the less PAR led to less water evaporation under the canopy of maize. In our experiment, the average soil temperature of the treatment $\mathrm{C}$ was the best in this experiment, which also increased water evaporation in soil and the soil humidity would be less. That is to say, PAR affects the yield of sweet potato indirectly through decreasing soil moisture. After all, sweet potato is one of drought-enduring and not waterlogging tolerance crops (Yan et al., 1964). The temperature range of C also was large between early morning and late afternoon, this accelerated tuberous roots growth and development of sweet potato. As Li (1995) reported, the large fluctuation of soil temperature was helpful to the production of sweet potato with mound planting in relay intercropping. The symbiotic stage for sweet potato and maize just continues from May to July, when rainfall is very abundant in southwestern areas, such as Chongqing and Sichuan in China. For ridging mode, it is more suitable for the wide-ridge and mound planting to drain away water than narrowridging that is easy to be waterlogged by maize stripe in raining days. This is just like what was shown by Figure 3 in this experiment.

As above results, the Pn correlated with tuberous root yield of sweet potato positively, which is coincidence with Li's report (2011). With the shadow of maize increasing, the diurnal changing curve of Pn became from double submits to single one. This may be related with the fact that the shaded leaves of sweet potato partly would be hurt less by suddenly strong sunlight, avoiding "noon depression" and photoinhibition of photosystem (Guo et al., 2007). Furthermore, the activity of the RuBisco changed little during from transplanting day to 65 th day and later it began to increase apparently after harvesting maize, Jiang also got the result as that, the Pn would cut down with the activity lowering (Jiang et al., 2001). Meanwhile the higher the content of RuBisco is, the higher Pn is (Weng et al., 2000; Jiang et al., 2001; Wang et al., 2003). The Pn of mound planting $(\mathrm{C})$ of sweet potato was the highest, which may benefit from this planting mode providing more active RuBisco than the two others. Through regressive analysis, we found that the activity of SPS contributed to the yield of sweet potato greatly. For maize and potato, the resembling results were obtained by Causse et al. (1995) and Ishimaru et al. (2008). Ishimaru even treated the activity of SPS as the key trait for 
breeding new hybrid maize. So, to a certain extent, the activity of both RuBisco and SPS determine the yield of sweet potato.

Microbial biomass is one of reservoir of soil nutrients to utilize for plants and the (Zhao et al., 2006). The intercropping mode was instrumental in lifting the diversity of soil microorganisms of rhizosphere soil, and it affected the absorption and utilization of soil nutrients. In this experiment, the microbial biomass of different treatments was not same and the content of nutrition was different too. Therein the mound planting was the optimal to increase microbial biomass and nutritious utilization, all of which would be owing to the shadow of maize indirectly, under this condition microorganisms would grow fast and become to more diversity.

Many researches indicated the advantage of maize was more than sweet potato in intercropping system and the yield loss of sweet potato was large obviously (Zhu et al., 1993; Cui et al., 1997; Huang et al., 2011; Xiao et al., 2013), and we also testified in this experiment. The yield of corn was influenced by sweet potato a little even or less. All the results suggest that the superiority of relay intercropping should be more determined through sweet potato yield in production. The sole method to resolve this essential problem is to provide profitable conditions for growth of lower crops population and guarantee their economic yield.

\section{Conclusions}

For the different ridging modes, planting sweet potato in the middle rows of maize ( $A$ and $C$ ) was better than planting on both side rows of maize (B) in this experiment. Especially from the two-year results, the mound planting could provide more profitable symbiotic ecological environment and get more yield of sweet potato as well as population benefits.

\section{Acknowledgements}

This work was supported by Chongqing Science and Technology Bureau (Grant No. cstc2015shmsztzx80001 and cstc2019jscx-msxmX0326).

\section{Conflict of Interests}

The authors declare that there are no conflicts of interest related to this article.

\section{References}

Bao SD (2000). Agricultural chemistry analysis of soil. Beijing: China Agriculture Press, pp 263-270.

Beets WC (1982). Multiple cropping and tropical farming system. Colorado, USA: Grower. London, Britain and West views press.

Causse M, Rocher JP, Pelleschi S, Barrière Y, de Vienne D, Prioul JL (1995). Sucrose-phosphate synthase: an enzyme with heterotic activity correlated with maize growth. Crop Science 35(4):995-1001.

Clawson DL (1985). Harvest security and intraspecific diversity in traditional tropical agriculture. Economic Botany 39(1):56-67.

Coll L, Cerrudo A, Rizzalli R, Monzon JP, Andrade FH (2012). Capture and use of water and radiation in summer intercrops in the south-east Pampas of Argentina. Field Crops Research 134:105-113.

Cui M, Wang YB, Bai XK (1997). Study on different types of intercropping strips with summer maize and sweet potato. Maize Science 5(4):62-64. 
Gliessman SR (1985). Agro: ecological processes in sustainable agriculture. Chelsea, ML, USA: Sleeping Bear Press.

Guo BL, Yang JX, Lu RQ, Wu Y, Guo J, Li XY (2007). Effects of shade treatment on the growth and photosynthesis characteristics of Euonymus fortune. Acta Horticulturate Sinica 34(4):1033-1036.

Huang YM, Chen TY, Li YQ (2011). Benefit study on intercropping patterns of maize and sweet potato. Journal of Guangxi Agriculture 26(6):16-19.

Ishimaru K, Hirotsu N, Kashiwagi T, Madoka Y, Nagasuga K, Ono K, Ohsugi R (2008). Overexpression of a maize SPS gene improves yield characters of potato under field conditions. Plant Production Science 11(1):104-107.

Jiang D, Lu Q, Weng X, Zheng B, Xi H (2001). Role of key enzymes for photosynthesis in the diurnal changes of photosynthetic rate in rice. Acta Agronomica Sinica 27(4):301-307.

Jiang DA, Weng XY, Lu Q, Zheng B (2001). Effect of light and dark treatments on photosynthetic key enzymes in rice. Journal of Zhejiang University (Agriculture and Life Sciences) 27(4):355-360.

Li CX (2011). Study on correlation between major photosynthetic properties and characteristics related to yield and quality of potato. Northeast Agricultural University. Ph. D thesis. pp 27-28.

Li YQ (1995). Study on mechanism of increase in output of mound planting sweet potato interplanting with maize. Tropical and Subtropical Soil Science 4(4):207-210.

Liu CW, Wang Q, Liu QL, Guan XK, Yang Y, Zhang EH (2013). Effect of stubble-standing mode on the grain yield and water use efficiency of wheat and maize in w heat/maize intercropping system. Journal of Applied Ecology 24(2):438-443.

Liu GY, Liang J, Wei M (2011). Photoinhibition and recovery of rice leaf from shadow to high light. Journal of Southwest China Normal University (Natural Science Edition) 36(5):156-158.

Liu XZ, Zhang YJ, Du HL (2004). Effects of moisture-fertilizer interaction on the yields of maize and soybean under the condition of inter-cropping. Chinese Journal of Eco-Agriculture 12(3):75-77.

Liu YH, Zhang LF (1994). Essential and application analysis of land equivalent ratio. Farming System and Cultivation 4:64.

Ma DF (2013). Thought about some problems of sweet potato industrial development in China. Agriculture Engineering Technology (Agricultural Product Processing Industry) 2013(11):21-24.

Mead R, Willey RW (1980). The concept of a land equivalent ratio and advantages in yields from intercropping. Experimental Agriculture 16:217-228.

Nedunchezhiyan M, Byju G, Jata SK (2012). Sweet Potato Agronomy. Fruit, Vegetable and Cereal Science and Biotechnology 6(1):1-10.

Oswald A, Alkamper J, Midmore D J (1995). The effect of different shade levels on growth and tuber yield of sweet potato: II. tuber yield. Journal of Agronomy and Crop Science 175:29-40.

Prithiviraj B, Carruthers K, Fe Q, Cloutier D, Martin RC, Smith DL (2000). Intercropping of corn with soybean and lupin for silage: effect of seeding date on yield and quality. Journal of Agronomy and Crop Science 185(2):129136.

Rezaei-Chianeh E, Nassab ADM, Shakiba MR, Ghassemi-Golezani K, Aharizad S, Shekari F (2011). Intercropping of maize (Zea mays L.) and faba bean (Vicia faba L.) at different plant population densities. African Journal of Agricultural Research 6(7):1786-1793.

Skelton LE, Barrett GW (2005). A comparison of conventional and alternative agroecosystems using alfalfa (Medicago sativa) and winter wheat (Triticum aestivum). Renewable Agriculture and Food Systems 20(1):38-47.

Wang N, Jiang D, Hong J, Feng Z, Xiao-Yan W (2003). Diurnal changes of RuBisco and RCA activities and their cellular localization in rice. Journal of Integrative Plant Biology 45(9):1076-1083.

Wang XP, Li BG, Guo Y, Zhai Z (2004). Measurement and analysis of the 3D spatial distribution of photosynthetically active radiation in maize canopy. Acta Agronomica Sinica 30(6):568-576.

Wells AT, Chan KY, Cornish PS (2000). Comparison of conventional and alternative vegetable farming systems on the properties of a yellow earth in New South Wales. Agriculture, Ecosystems and Environment 80:47-60.

Weng XY, Jiang DA, Zhang F (2002). Gene expression of key enzymes for photosynthesis during flag leaf senescence of rice after heading. Journal of Plant Physiology and Molecular Biology 28(4):311-316.

Willey R (1979). Intercropping - Its importance and research needs. Part 1. Competition and yield advantages. Field Crops Abstracts 32:1-10.

Wolfe MS (1985). The current status and prospects of multiline cultivars and variety mixtures for disease resistance. Annual Review of Phytopathology 23(23):251-273. 
Wu JS, Lin QM, Huang QY (2006). Measuring method and application of microbial biomass in soil. Beijing: China Meteorological Press.

Wu YS, Gong WZ, Liao DP, et al (2015). Effects of shade and light recovery on soybean cultivars (lines) and its relationship with yield in relay strip intercropping system. Acta Agronomica Sinica 41(11):1740-1747.

Xiao G, Long W, Zhao P, Guo H (2013). Photosynthetic characteristics and yield of corn and sweet potato in monoculture and intercropping. Journal of Yunnan Agricultural University 28(1):52-55.

Xu DQ, Zhang YZ, Zhang RX (1992). Photoinhibition of photosynthesis in plants. Plant Physiology Communications $28(4): 237-243$.

Yan ZD, Zhu CZ, Sheng JL (1964). Studies on the drought resistant characters of sweet potato varieties. Acta Agronomica Sinica 3(2):183-194.

Yong TW, Yang WY, Wang XC, Fan GQ (2009). Nitrogen uptake and utilization and interspecies reciprocity in the two relay-planting systems. Journal of Sichuan Agricultural University 27(2):167-172.

Yong TW, Yang WY, Xiang DB, Wan Y, Liu W, Wang X (2012). Effect of wheat/maize/soybean and wheat/maize/sweet potato relay strip intercropping on soil nitrogen content and nitrogen transfer. Acta Agronomica Sinica $38(1): 148-158$.

Zhang QT (2015). Sweet potato in western China. Chongqing: Southwest Normal University Press, pp 242-245.

Zhao XL, Cheng HT, Lv GH (2006). Advances in soil microbial biomass. Journal of Meteorology and Environment 22(4):68-72.

Zhou LJ, Xie YQ, Xu W, Guo QH, Dai S, Zhao SJ, Song JM (2015). Effects of full sunlight after shading on photosynthetic characteristics of Xiaoyan 54 and 8602, and their hybrids. Acta Agronomica Sinica 41(5):813-81.

Zhu JQ, Chu TF, Xu MS (1993). Study on intercropping adaptability of sweet potato under the maize community. Journal of Zhejiang Agriculture 5:202-205.
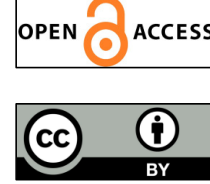

The journal offers free, immediate, and unrestricted access to peer-reviewed research and scholarly work. Users are allowed to read, download, copy, distribute, print, search, or link to the full texts of the articles, or use them for any other lawful purpose, without asking prior permission from the publisher or the author.

License - Articles published in Notulae Botanicae Horti Agrobotanici Cluj-Napoca are Open-Access, distributed under the terms and conditions of the Creative Commons Attribution (CC BY 4.0) License. (c) Articles by the authors; UASVM, Cluj-Napoca, Romania. The journal allows the author(s) to hold the copyright/to retain publishing rights without restriction. 